\title{
DISPUTAS ELEITORAIS E LIDERANÇAS OPERÁRIAS NO INÍCIO DA PRIMEIRA REPÚBLICA: O PERFIL SOCIAL E A VOTAÇÃO DE MEMBROS DO PARTIDO OPERÁRIO DO PARANÁ (1890-1896)
}

\author{
ELECTORAL COMPETITION AND WORKERS' LEADERS IN THE \\ BEGINNING OF THE FIRST REPUBLIC: THE SOCIAL PROFILE \\ AND THE ELECTORAL PERFORMANCE OF MEMBERS OF \\ WORKER PARTY OF PARANÁ (1890-1896)
}

Sandro Aramis Richter Gomes ${ }^{1}$

RESUMO: Neste artigo desenvolve-se uma investigação acerca do perfil social e do desempenho eleitoral de integrantes do Partido Operário (PO) que existiu no Estado do Paraná, em um período que abrange os anos de 1890 a 1896. Por meio de um estudo de caso, o objetivo desta análise é avançar no entendimento sobre a organização interna e a ação eleitoral dos partidos operários que surgiram no Brasil do início da Primeira República. Há três argumentos sustentados neste artigo. Primeiro, demonstra-se que o PO era comandado por veteranos que, no contexto do Segundo Reinado, já estavam integrados à cena política paranaense. Segundo, cabe evidenciar que essa agremiação não possuía relevante força eleitoral. Terceiro, é ressaltado que foi breve a aliança entre os fundadores desse partido. Em meados dos anos 1890, eles já se encontravam politicamente afastados.

PALAVRAS-CHAVE: Competição eleitoral; lideranças operárias; partidos políticos; Primeira República.

ABSTRACT: This article analyzes the social profile and electoral performance of members of the Workers' Party (PO), which existed in the State of Paraná between the years 1890 to 1896 . Through a case study, the purpose of this analysis is to advance the understanding of internal organization and the electoral action of the workers' parties that emerged in Brazil in the beginning of the First Republic. There are three arguments sustained in this article. First,

\footnotetext{
* O presente artigo contém os resultados da primeira etapa do estágio Pós-Doutorado realizado no Programa de Pós-Graduação em História da Universidade Federal do Paraná (UFPR), no biênio 2018-2019.

${ }^{1}$ Graduado (2009), mestre (2012) e doutor (2017) em História pela UFPR. Realiza estágio de Pós-Doutorado no Programa de Pós-Graduação em História da UFPR. Endereço: Ed. D. Pedro I, Rua General Carneiro, 460, Centro, Curitiba, Paraná. E-mail: argomes8@ gmail.com. ORCID: http://orcid.org/0000-0002-6790-4958
} 
the PO was commanded by veterans who, in the context of the Second Reign, were already integrated into the Paraná political scene. Second, this party did not have significant electoral strength. Third, the alliance between the founders of this party it was ephemeral. By the mid-1890s, they were already politically distanced.

KEYWORDS: Electoral competition; First Republic; worker leaderships; political parties.

\section{Introdução}

Neste estudo realiza-se uma investigação a respeito do perfil social e do desempenho eleitoral de lideranças do Partido Operário (PO) que atuou no Estado do Paraná no início da Primeira República. Por meio de um estudo de caso, o objetivo desta análise é avançar no entendimento sobre a organização interna e as formas de ação eleitoral dos partidos operários que surgiram no Brasil após o fim do regime monárquico.

O recorte temporal aqui adotado abrange os anos de 1890 a 1896. O ano de 1890 diz respeito à época do surgimento do PO. O ano de 1896, por seu turno, foi o momento em que a agremiação participou de seus últimos pleitos eleitorais. Portanto, esse recorte temporal abrange as etapas de formação e desagregação do primeiro partido operário do Paraná.

Há três argumentos sustentados no decorrer desta investigação. Primeiro, cumpre evidenciar que uma parcela dos dirigentes do PO começou a participar da vida política na época do Segundo Reinado. Essa agremiação serviu como um refúgio para indivíduos que, anteriormente à implantação da República, já pertenciam ao quadro partidário do Paraná. O desenvolvimento de tal argumento permite evidenciar que a criação do PO foi liderada por indivíduos que possuíam um treinamento em tarefas como a gestão de diretórios partidários e a organização de campanhas eleitorais. Os novatos, portanto, ocuparam posições menos proeminentes na vida interna dessa agremiação.

Segundo, demonstra-se que o PO era eleitoralmente pouco competitivo. O êxito dos seus candidatos dependia de artifícios como a não apresentação de uma chapa completa pelo partido situacionista. Em virtude da limitada base de 
apoiadores e da dependência em relação às decisões dos governistas sobre a formação de chapas, foi pouco frequente a participação de membros do PO nas instituições legislativas.

Terceiro, cumpre destacar que foi pouco duradoura a aliança entre os fundadores dessa agremiação. A eleição parlamentar de 1896 foi o momento derradeiro em que tais lideranças estiveram unidas. Nesse período, o PO não era a única agremiação paranaense que contava com a presença de trabalhadores urbanos. Assim, a concorrência com outros partidos minoritários, a perda de correligionários e a baixa integração entre os membros da oposição estadual foram fatores que minaram a força política do PO.

Os estudos acerca da ação política dos operários ao tempo da Primeira República possuem uma característica comum. Tais abordagens dedicam atenção às origens e à estrutura interna de associações de trabalhadores urbanos. Essa vertente de análise tem contribuído para o entendimento de processos como a ascensão de lideranças operárias. Ela também possibilita uma compreensão atinente à natureza das reivindicações e aos efeitos da mobilização política dessas associações. Tal corrente de investigação é inerente, por exemplo, aos trabalhos sobre o movimento operário do Estado do Rio Grande do Sul (BILHÃO, 1999; LONER, 2010; PETERSEN, 2001; SCHMIDT, 2000; SCHMIDT, 2004). ${ }^{2}$

Concernente ao caso paranaense, é episódico o aparecimento de estudos referentes à articulação política entre setores do operariado. Há tempos, a ênfase de tais análises recai sobre temas como a eclosão de manifestações de trabalhadores e as formas de contenção dessas manifestações pelas autoridades

\footnotetext{
${ }^{2}$ A historiografia sobre as associações operárias do Brasil desenvolve-se há décadas. Existem trabalhos referentes à atividade política de trabalhadores de distintos estados. Os estudos cruciais dessa área de estudos dizem respeito, por exemplo, ao conteúdo das propostas sustentadas por entidades de classe em estados como São Paulo (CARONE, 1979; FAUSTO, 1976; LINHARES, 1977). Antigas abordagens acerca dos partidos estaduais da Primeira República também propiciaram um entendimento sobre ação de agremiações operárias em estados como Bahia e Rio de Janeiro (CHACON, 1981; LOBO, 1992; SAMPAIO, 1999). De outra parte, a análise do estado da arte aqui efetuada é voltada à recensão de trabalhos contemporâneos a respeito das agremiações operárias. A atenção às abordagens mais recentes permite identificar os aspectos pouco desenvolvidos do estudo sobre a ação eleitoral de lideranças operárias nos anos seguintes ao fim do Império.
} 
do Estado. Verifica-se, também, a inclinação para o estudo das ideias veiculadas em órgãos da imprensa operária (ARAÚJO e CARDOSO, 1992). As abordagens a respeito da ação política de trabalhadores urbanos do Paraná são orientadas pelo propósito de salientar a renitente disposição de distintas associações de classe para se articularem em nome da concretização de um preciso conjunto de demandas (FONSECA e GALEB, 2017; VASCO, 2006).

De fato, encontra-se em desenvolvimento uma inovação nos estudos acerca dos trabalhadores urbanos de distintas regiões do Brasil. Tal inovação consiste na análise da ação política de operários negros que se envolveram em associações de classe no decorrer da Primeira República. Essa corrente de estudos tem evidenciado a diversidade de agremiações políticas e recreativas que congregaram descendentes de escravos (FABRIS e MENDONÇA, 2019; PEREIRA, 2017; SAYÃO, 2015).

Cumpre mencionar que o estudo sobre o grau de politização de setores do operariado brasileiro nas primeiras décadas do século XX não é marcado pela análise da estrutura interna das agremiações partidárias às quais os trabalhadores pertenceram. Por consequência, permanece pouco conhecida a posição ocupada por esses profissionais na hierarquia administrativa dos partidos. Mais precisamente, remanesce pouco avançado o entendimento sobre as diferenças internas aos operários quanto às funções que desempenharam no interior de partidos. Ao mesmo tempo, mantém-se em estágio incipiente a compreensão acerca da força eleitoral desses profissionais em eleições estaduais.

As abordagens sobre o ingresso de trabalhadores nos partidos políticos são mais desenvolvidas no que concerne ao contexto dos anos finais da Primeira República (DOMINGUES, 2017; KAREPOVS, 2006; PRADO, 2019). O estudo de Aldrin Castellucci acerca da atividade eleitoral do Partido Operário da Bahia permanece como uma referência para a compreensão dos processos de construção e ocaso de um projeto de ação política efetuado por trabalhadores no Brasil dos anos 1890 (CASTELLUCCI, 2008). 
Em grande medida, as análises respeitantes à vida partidária da Primeira República conferem maior ênfase à estrutura interna e ao desempenho eleitoral das agremiações situacionistas. Nesse âmbito, os partidos minoritários constam como elementos periféricos de um quadro político marcado pelo estável domínio das agremiações governistas. Tal característica é inerente aos estudos sobre o jogo político de estados como o Paraná e o Rio de Janeiro (FERREIRA, 1994; GOULART, 2008).

Há dois aspectos da atividade política de trabalhadores urbanos que não obtiveram especial atenção da historiografia. Um aspecto é referente à natureza dos vínculos políticos cultivados por dirigentes de partidos operários ao longo do Segundo Reinado. Tal perspectiva de análise permite salientar que não era incomum a existência de lideranças operárias que, na época do Império, pertenceram a círculos sociais compostos por membros de elites locais. O estudo do caso do PO permite evidenciar que a aproximação com tais elites foi crucial para que uma parte dos dirigentes dessa agremiação conquistasse suas primeiras oportunidades de atuação nas lides partidárias.

O segundo aspecto pouco desenvolvido no estudo da ação política dos trabalhadores urbanos é referente ao desempenho eleitoral dos partidos aos quais se filiaram. Desse modo, permanece incompleta a tarefa de reconhecer os limites da competitividade eleitoral de membros das agremiações minoritárias. Em suma, mantêm-se pouco desenvolvidos os estudos direcionados a comparar o desempenho eleitoral das agremiações operárias que funcionaram no Brasil dos últimos anos do século XIX.

Por fim, cumpre mencionar que o presente trabalho emprega métodos de análise inspirados na prosopografia, a qual consiste no estudo de trajetórias coletivas (CHARLE, 2006; STONE, 2011). Um elemento comum às análises prosopográficas consiste na reunião massiva de informações a respeito das carreiras políticas e profissionais. Tal perspectiva de investigação é decisiva para identificar de padrões de carreira dos membros de uma geração (FERRARI, 2010). Por conseguinte, o prosopográfico dos percursos dos dirigentes e candidatos do PO permite destacar analogias quanto aos modos de 
ingresso de lideranças operárias na vida partidária paranaense no contexto das décadas finais do século XIX. ${ }^{3}$ A análise comparado dos percursos políticos e profissionais de tais lideranças também permite reconhecer as distinções acerca da atividade partidária desenvolvida pelos fundadores do PO no contexto da Primeira República. Em síntese, o desenvolvimento dessa abordagem favorece a produção de conhecimento sobre as etapas das carreiras políticas dos personagens centrais da mencionada agremiação.

Os membros do núcleo dirigente do PO: origens de suas carreiras políticas

O propósito desta seção é identificar a natureza da atividade política desenvolvida por próceres do PO nos anos finais do Império. Cumpre evidenciar que o surgimento dessa agremiação decorreu de uma efêmera aliança entre republicanos históricos, conservadores e liberais. Fundado na cidade de Curitiba, a 22 de junho de 1890, o PO foi um partido estadual de oposição. Ele contou com o respaldo de novatos na vida política. Em grande medida, esses novatos exerciam ofícios artesanais. A formação desse partido foi uma iniciativa apoiada majoritariamente por operários e artífices residentes na capital paranaense (GOULART, 2008, p.302).

No entanto, alguns dos seus dirigentes já possuíam experiência na cena política regional. O PO, assim, foi comando por indivíduos cultivavam antigos vínculos chefes partidários da província. Foram esses veteranos que conquistaram as posições mais relevantes na gestão da nova agremiação. As conexões sociais mantidas por alguns dos fundadores do PO eram multifacetadas. Desse modo, trata-se de ressaltar que a socialização com integrantes das elites de municípios do litoral e do primeiro planalto paranaense foi crucial para que uma parte dos dirigentes dessa agremiação conquistasse um espaço na cena política da província. A análise dos primórdios da ação política de tais dirigentes demanda o estudo das informações contidas no Quadro 1.

\footnotetext{
${ }^{3}$ A obtenção de tais informações foi efetuada por meio da análise de jornais paranaenses. Esses periódicos estão disponíveis para consulta no sítio eletrônico da Hemeroteca Digital Brasileira: $<$ memoria.bn.br>
} 
Quadro 1 - Atuação política e profissional dos membros da Comissão Executiva do Partido Operário do Paraná

\begin{tabular}{|c|c|c|c|c|c|}
\hline Nome & $\begin{array}{c}\text { Município } \\
\text { de origem }\end{array}$ & Profissão & $\begin{array}{c}\text { Filiação } \\
\text { partidária } \\
\text { (anterior a } \\
\mathbf{1 8 9 0}\end{array}$ & $\begin{array}{c}\text { Total de cargos } \\
\text { comissionados } \\
\text { (exercidos até } \\
\mathbf{1 8 9 0}\end{array}$ & $\begin{array}{c}\text { Total de } \\
\text { mandatos no } \\
\text { Poder } \\
\text { Legislativo } \\
\text { (exercidos } \\
\text { até 1890) }\end{array}$ \\
\hline $\begin{array}{c}\text { Agostinho } \\
\text { Leandro da } \\
\text { Costa }\end{array}$ & $\begin{array}{c}\text { Morretes } \\
\text { (PR) }\end{array}$ & Empresário & $\begin{array}{c}\text { Partido } \\
\text { Republicano }\end{array}$ & 0 & 1 \\
\hline $\begin{array}{c}\text { João } \\
\text { Crispim } \\
\text { Caetano da } \\
\text { Silva }\end{array}$ & $\begin{array}{c}\text { Curitiba } \\
\text { (PR) }\end{array}$ & Encadernador & - & 0 & 0 \\
\hline $\begin{array}{c}\text { Justiniano } \\
\text { de Mello e } \\
\text { Silva }\end{array}$ & $\begin{array}{c}\text { Laranjeiras } \\
\text { (SE) }\end{array}$ & Advogado & $\begin{array}{c}\text { Partido } \\
\text { Conservador }\end{array}$ & 2 & 3 \\
\hline
\end{tabular}

Fontes: Dezenove de Dezembro (PR); Gazeta de Notícias (RJ); Gazeta Paranaense (PR); Jornal do Comércio (RJ); O Paranaense (PR); Província do Paraná (PR)

O estudo de Quadro 1 permite destacar que uma parte dos líderes do PO exercera mandatos eletivos ao tempo do Segundo Reinado. Portanto, as informações presentes neste Quadro possibilitam sustentar a afirmação de que a fundação desse partido não foi uma iniciativa deflagrada unicamente por novatos da cena partidária.

Cabe também destacar que os políticos veteranos que se integraram ao PO diferiam entre si em virtude dos seus modos de inserção nas lides partidárias. $\mathrm{O}$ reconhecimento das diferenças que existiram entre as carreiras desses veteranos possibilita evidenciar que a criação do PO não foi motivada por um longo convívio entre os seus fundadores. Em boa medida, o surgimento dessa agremiação decorreu da aproximação entre políticos que, nos anos finais do Império e nos primeiros momentos do regime republicano, não obtiveram posições de destaque nos partidos existentes no Paraná. A fundamentação de tais afirmações exige o estudo das etapas capitais do percurso político do advogado sergipano Justiniano de Mello e Silva (1852-1940).

Dentre os fundadores do PO, ele foi o primeiro a se envolver em atividades políticas. Esse envolvimento principiou nos anos 1870. Mello desenvolveu uma carreira que possui semelhanças com os percursos dos bacharéis de sua geração. Ao tempo do Império, o exercício de funções 
comissionadas, a conquista de cargos nos diretórios dos partidos monárquicos e o exercício de mandatos eletivos foram inerentes às trajetórias de uma parcela expressiva dos graduados em Direito (CARVALHO, 2007).

Justiniano de Mello obteve de modo célere posições relevantes na vida política e administrativa da Província do Paraná. Em 1876, aos 24 anos de idade, foi nomeado secretário do Governo da Província do Paraná (DEZENOVE DE DEZEMBRO, 12 fev. 1876, p.4). Tratava-se de uma época em que os conservadores comandavam os esquemas de preenchimento de cargos públicos.

A Secretaria de Governo era um órgão capital na estrutura administrativa das províncias. A esse respeito, cabe mencionar que em meados dos anos 1870 os secretários dos Governos provinciais conheceram o aumento de suas prerrogativas. Nesse contexto, eles passaram a exercer o controle sobre duas diretorias e cinco seções da administração das províncias. Em última análise, os secretários tinham a incumbência de supervisionar o trabalho de distintas repartições (TORRES, 2017). Dessa forma, Justiniano de Mello pertenceu à geração de secretários de Governo cujas competências administrativas eram muito acentuadas.

No Paraná, desde os anos 1850, o exercício do posto de secretário de Governo era um estágio inicial do treinamento do jovem adventício nos assuntos políticos e administrativos. Comumente, o desempenho do cargo de presidente de província era uma etapa seguinte ao exercício da função de secretário. ${ }^{4}$ A filiação a um partido era outra característica do percurso dos ocupantes de tal posto. ${ }^{5}$

Nessa época, Justiniano de Mello acumulou o referido cargo com a função de diretor interino da Instrução Pública do Paraná (DEZENOVE DE DEZEMBRO, 10 jan. 1877, p.3). Foi no ano de 1877 que esse bacharel

\footnotetext{
${ }^{4}$ Em 1857, por exemplo, o piauiense José Martins Pereira de Alencastre (1831-1871) foi secretário do Governo do Paraná. Em 1861, assumiu a presidência da província de Goiás. Ele exerceu tal função até o ano de 1863. Em 1866, por fim, foi investido no posto de presidente de Alagoas, no qual permaneceu até 1867 (MACEDO, 1876).

${ }^{5}$ Em 1862, o bacharel paulista Sérgio Francisco de Souza Castro (1840-1921) tornou-se secretário do Governo do Paraná. Após o exercício desse posto, ele se vinculou ao Partido Liberal e desenvolveu uma carreira política nessa província (CHAVES e VARGAS, 1987).
} 
formalizou o seu ingresso no Partido Conservador. ${ }^{6}$ Em tal ano, ele se tornou $2^{\circ}$ vice-presidente do diretório que essa agremiação instalara no Paraná (O PARANAENSE, 29 set. 1877, p.4). O apoio das lideranças conservadores the propiciou a conquista de um mandato de deputado provincial, em 1878 (ALVES, 2014).

O início de sua trajetória política foi marcado pela aproximação com os próceres locais do Partido Conservador. Os principais efeitos dessa aproximação foram limitados aos anos 1870. O vínculo com os chefes regionais do partido lhe propiciou uma indicação para ingressar no magistério público do Paraná. ${ }^{7}$

Em um sentido amplo, Mello se enquadra na categoria dos bacharéis que ambicionaram amealhar posições estáveis no funcionalismo paranaense. A conquista dessas posições representou o limite dos benefícios decorrentes do envolvimento em esquemas de nomeações para postos da administração provincial. Aos membros de tal categoria, o exercício de mandatos eletivos e de cargos em diretórios partidários era apenas eventual. ${ }^{8}$

Portanto, o PO incorporou aos seus quadros um indivíduo que, na época da implantação da República, estava afastado havia mais uma década de posições centrais na cena partidária da província. Em verdade, às vésperas da queda do Império Justiniano de Mello articulou a formação de uma dissidência no Partido Conservador paranaense. Essa dissidência originou um diretório cujas atividades se estenderam até os dias seguintes ao advento do regime republicano (A REPÚBLICA, 21 nov. 1889, p.3).

Todavia, os antagonistas do diretório oficial não reuniram os apoios necessários para lançar candidatos competitivos. Eles também não obtiveram o

\footnotetext{
${ }^{6}$ Em fins de 1877, também houve a exoneração de Justiniano de Mello do cargo de secretário de Governo do Paraná (DEZENOVE DE DEZEMBRO, 2 jan. 1878, p.2).

${ }^{7}$ Em 1878, o referido bacharel assumiu as cadeiras de Gramática e Pedagogia do Instituto Paranaense. Esse estabelecimento de ensino estava sediado na cidade de Curitiba (DEZENOVE DE DEZEMBRO, 26 jun. 1878, p.4).

${ }^{8}$ O advogado Tertuliano Teixeira de Freitas (1834-1910) pertencia a esse grupo. Filiado ao Partido Conservador, ele conheceu a redução de sua influência política nos anos 1880. Ao tempo do Segundo Reinado, tornou-se professor de Matemática do Instituto Paranaense. De modo análogo ao caso de Mello, Freitas permaneceu ligado a esse estabelecimento de ensino no início da Primeira República (ALVES, 2014).
} 
respaldo de conservadores do interior da província para promover o crescimento da ala dissidente da agremiação (GAZETA PARANAENSE, 16 mar. 1889, p.1). Dessa forma, um ano antes da criação do PO Justiniano de Mello tentou recuperar a influência que exercera sobre o Partido Conservador paranaense no fim dos anos 1870. No rol de fundadores do PO, Mello era o político que formara uma base eleitoral mais consistente durante o Segundo Reinado. Ele possuía maior experiência em participar eleições como candidato oposicionista. $^{9}$

De outra parte, convém reconhecer que a defesa da ordem republicana e de demandas de setores do operariado não foi desenvolvida nos primórdios da carreira de Justiniano de Mello. A sua proscrição do comando do Partido Conservador não o impeliu, por exemplo, a se vincular aos republicanos históricos. Nos anos derradeiros da Monarquia brasileira, ele era um crítico do movimento que pregava a mudança de regime político. ${ }^{10}$

Em última análise, nota-se que a criação do PO permitiu que Mello retomasse a sua condição de liderança partidária. Essa retomada se tornou possível em virtude de sua aproximação com novos personagens da vida eleitoral brasileira - os operários. De outra parte, cabe destacar que o ingresso de Mello nessa agremiação também foi proveitoso para as lideranças operárias do Paraná.

Para sustentar tal afirmação, cabe salientar que o citado bacharel possuía longa experiência em comandar jornais de cunho político. O seu jornal Sete de Março, originalmente um órgão de apoio aos conservadores dissidentes, tornouse um instrumento da propaganda do PO durante as eleições de 1890 (SETE DE MARÇO, 6 set. 1890, p.4).

\footnotetext{
${ }^{9}$ Em 1882, época em que os conservadores pertenciam ao campo da oposição, Justiniano de Mello foi o candidato a deputado provincial mais votado do $2^{\circ}$ distrito eleitoral do Paraná (DEZENOVE DE DEZEMBRO, 29 mar. 1882, p.4). Em setembro de 1889, momento em que o Partido Conservador voltou a fazer oposição ao Gabinete Ministerial, Mello conseguiu um novo mandato à Assembleia Provincial pelo $1^{\circ}$ distrito (DEZENOVE DE DEZEMBRO, 2 set. 1889, p.2).

${ }^{10}$ No entendimento de Justiniano de Mello, os republicanos incorriam em erro ao classificar a Monarquia como um regime político fundado no privilégio de uma família. Ele argumentou que tal regime fora criado "em atenção ao interesse geral, à paz pública e à proteção da liberdade" (SETE DE MARÇO, 28 nov. 1888, p.2).
} 
Dentre os expoentes da nova agremiação, Mello despontava como o correligionário dotado de maior experiência na gestão de diretórios partidários. Ele tivera a oportunidade de pertencer tanto do diretório oficial quanto do diretório dissidente do Partido Conservador paranaense. Assim, as lideranças operárias do estado não surgiram na cena política por meio da rejeição a qualquer forma de aliança com os egressos dos partidos monárquicos.

A fundação do PO também propiciou o crescimento da projeção de outro veterano nas lides partidárias, a saber, Agostinho Leandro da Costa (1857-1904). Ele iniciara o seu percurso político no município litorâneo de Morretes, onde nascera. A conquista de um espaço na cena partidária do Paraná é um indicador da mobilidade social vivenciada por tal indivíduo. Ele era filho de um casal de pardos e sua primeira experiência profissional foi como aprendiz de alfaiate (FABRIS, 2019).

A despeito da modesta condição econômica, Agostinho Leandro se integrou a um círculo social composto por abastados comerciantes de sua cidade natal. Essa integração foi concretizada início dos anos 1880. Ao tempo de sua juventude, ele já pertencia a instituições que contavam com a presença desses comerciantes. Assim, cumpre dedicar atenção a duas informações sobre os primórdios do percurso político e profissional de Agostinho Leandro.

Primeiro, cabe salientar que, em 1882, o futuro presidente do PO se tornou vereador de Morretes. Nessa ocasião, angariou 16 votos. Filiado ao Partido Liberal, ele obteve a segunda vaga na eleição de segundo escrutínio para tal cargo. Agostinho Leandro foi o menos votado entre os vereadores eleitos nessa ocasião (DEZENOVE DE DEZEMBRO, 2 ago. 1882, p.3). O segundo escrutínio era a eleição à qual concorriam os candidatos que tiveram menos sufrágios em primeira votação. Desse modo, o futuro líder operário estreou na cena partidária na condição de candidato pouco competitivo. A existência de expedientes como a eleição exclusiva para os postulantes menos votados foi crucial para que ele obtivesse um mandato à Câmara de Morretes. ${ }^{11}$

\footnotetext{
${ }^{11}$ Nessa ocasião, houve vereadores eleitos em segundo escrutínio em Morretes e Paranaguá que não pertenciam ao Partido Liberal. Em Morretes, Pedro Alexandre Franklin foi o mais votado em tal escrutínio, com 18 sufrágios. Ele havia exercido o cargo de vereador pelo Partido
} 
Em tal contexto, o Partido Liberal exercia o controle do Governo do Paraná e da Assembleia Legislativa. Essa agremiação também possuía o comando das Câmaras Municipais (ALVES, 2014). Assim, Agostinho Leandro se iniciou na vida política na condição de membro de um partido situacionista. Ao mesmo tempo, cabe salientar que esse empresário angariou o apoio da elite política local para exercer, em 1883, a presidência da Câmara de Morretes (DEZENOVE DE DEZEMBRO, 8 jan. 1884, p.2). Aos 26 anos, portanto, esse Leandro havia alcançado uma posição de relevo na cena política de tal município.

A segunda evidência da absorção desse indivíduo à elite morretense consiste em sua adesão a um protesto formulado pelos negociantes dessa cidade. Em 1883, ele participou de uma reunião na qual foi registrado em ata o descontentamento dos comerciantes locais com Governo da província. Tal descontentamento derivou da criação de um imposto sobre as movimentações comerciais realizadas pelos negociantes (GAZETA PARANAENSE, 21 mar. 1883, p.1).

Dentre os signatários da mencionada ata, havia membros da família Cordeiro. Desde os anos 1830, os integrantes de tal parentela dedicavam-se ao beneficiamento da erva-mate, participavam de instituições como a Câmara de Morretes e controlavam localmente o Partido Conservador (SANTOS, 1950).

Assim, o PO teve como presidente um negociante para o qual a socialização com comerciantes e dirigentes de partidos monárquicos foi crucial para que conseguisse auferir posições decisivas na vida econômica de Morretes. A ascensão econômica de Agostinho Leandro completou-se com sua migração para Curitiba, a capital paranaense. Foi em tal cidade que ele se consolidou como empresário. ${ }^{12}$ Em verdade, a realização de migração interna como forma

Conservador, nos anos 1870 (DEZENOVE DE DEZEMBRO, 11 out. 1876, p.3). O primeiro colocado no segundo escrutínio para vereador em Paranaguá foi Bernardo Soares Gomes Júnior, com 29 votos. Em tal época, ele estava integrado ao Núcleo Republicano do município (SIMAS, 1940). Em ambas as situações, os candidatos do Partido Liberal conquistaram as vagas de vereador em primeiro escrutínio. Assim, o segundo escrutínio era a oportunidade de membros do partido de oposição e de postulantes avulsos obterem um mandato.

$12 \mathrm{O}$ crescimento do poder econômico de Agostinho Leandro se tornou evidente no fim dos anos 1880. Em meados dessa década, ele atuou como proprietário de um botequim localizado na 
de conquistar novas oportunidades econômicas não foi incomum às trajetórias morretenses que pertenceram à geração de Agostinho Leandro. ${ }^{13}$

Cumpre, por fim, destacar a posição de tal indivíduo no quadro partidário paranaense nos meses anteriores à criação do PO. Em fins de 1888, Leandro formalizou sua saída do Partido Liberal. Em seguida, ingressou no Partido Republicano (DEZENOVE DE DEZEMBRO, 21 dez. 1888, p.1). Foi tardia a sua adesão à causa republicana, visto que nessa época já estavam estruturados os principais núcleos de propaganda republicana do Paraná (VERNALHA, 1989). Em suma, cabe destacar que os primeiros anos da atividade política de Agostinho Leandro foram marcados pela proximidade com chefes partidários ligados ao regime monárquico. $\mathrm{O}$ episódio de sua eleição para a presidência da Câmara de Morretes evidencia que ele obteve o apoio de tais chefes.

Em dezembro de 1889, ele era um apoiador do governador José Marques Guimarães, que fora nomeado para tal cargo pelo presidente Deodoro da Fonseca (A REPÚBLICA, 20 dez 1889, p.4). Ou seja, Agostinho Leandro teve uma rápida passagem pelo grupo governista instalado no Paraná após a queda do Império. No entanto, esse apoio aos situacionistas não foi acompanhado pela conquista de posições de destaque no Partido Republicano. Leandro se acomodou na qualidade de correligionário de uma agremiação que,

região central de Curitiba (DEZENOVE DE DEZEMBRO, 9 mai. 1884, p.4). Em seguida, fundou o Hotel Paraná. Ele também participou de uma sociedade comercial que promovia o abastecimento de carne verde na capital paranaense (DEZENOVE DE DEZEMBRO, 19 jan. 1889 , p.4). Desse modo, nos momentos finais do Império o futuro presidente do PO se mantinha inclinado a constituir laços econômicos e sociais com outros comerciantes.

${ }^{13}$ A esse respeito, atente-se ao caso do jornalista e historiador José Francisco da Rocha Pombo. Analogamente a Agostinho Leandro, ele nascera em Morretes no ano de 1857. Filho de um professor de ensino primário, Rocha Pombo migrou, no início dos anos 1880, para o município de Castro, situado no segundo planalto do Paraná. Em tal localidade, contraiu matrimônio com a filha de um fazendeiro. A parentela do cônjuge desse escritor estava ligada ao Partido Conservador. Foi por meio do apoio de lideranças conservadoras que ele conseguiu se eleger deputado à Assembleia Provincial do Paraná, em 1886 (BEGA, 2013). A análise dos casos de Agostinho Leandro e Rocha Pombo permite salientar que o vínculo com membros de elites locais foi uma ambição comum a esses contemporâneos. Essa ligação poderia ser concretizada por meio do envolvimento em esquemas matrimoniais - este foi o caso de Rocha Pombo. Ela também poderia ser realizada por intermédio da aproximação com comerciantes - tal foi o caso de Agostinho Leandro. Em síntese, a manutenção de ligações com indivíduos abastados lhes foi operacional para o exercício ocasional de funções políticas. 
em 1890, conferiu apoio às pretensões eleitorais de antigas lideranças conservadoras da província.

No contexto do fim do regime monárquico, Agostinho Leandro e Justiniano de Mello não participavam da gestão dos partidos aos quais pertenciam. Conforme ressaltado, Mello não conseguira recrutar relevantes adesões ao seu projeto de abrir dissidência no Partido Conservador do Paraná. Agostinho Leandro, por sua vez, não pertenceu ao grupo de dirigentes do Partido Republicano na província.

Nesse cenário, era apenas o secretário do PO, João Crispim, que não tivera qualquer ligação com partidos políticos. Ele não possuía vínculos com setores de elites locais. Nesse período, Crispim exercia um ofício artesanal. Ele atuava como encadernador. Anteriormente à fundação do PO, Crispim foi secretário de uma entidade de classe, o Clube dos Operários e Artistas Paranaenses (A REPÚBLICA, 29 jan. 1890, p.4). Tal associação foi o núcleo fundador do PO. Em última instância, esse partido era controlado por indivíduos marcados pela baixa projeção no cenário partidário. Ele também era gerido por um indivíduo (João Crispim) cujo envolvimento nas lides políticas se tornou mais consistente a partir do advento do regime republicano.

Inserção em setores de elites locais e envolvimento com o regime monárquico: o perfil social dos candidatos do PO à Assembleia Nacional Constituinte

O propósito desta seção é investigar a natureza da atividade política e profissional, ao tempo do Segundo Reinado, dos candidatos que o PO apresentou à Assembleia Nacional Constituinte em 1890. Em tal ano, esse partido lançou chapas completas aos cargos de senador e deputado constituinte. Portanto, o PO surgiu na cena política regional com um projeto eleitoral muito ambicioso. No Paraná, no contexto da Primeira República, não houve outro partido minoritário inclinado a disputar todas as vagas em uma eleição parlamentar. O estudo a respeito dos vínculos políticos e sociais dos postulantes do PO ao Senado exige, inicialmente, a atenção às informações presentes no Quadro 2. 
Quadro 2 - Atuação política e profissional dos candidatos ao Senado Federal pelo Partido Operário do Paraná

\begin{tabular}{|c|c|c|c|c|c|}
\hline Nome & $\begin{array}{l}\text { Município } \\
\text { de origem }\end{array}$ & Profissão & $\begin{array}{c}\text { Filiação } \\
\text { partidária } \\
\text { (anterior a } \\
\text { 1890) }\end{array}$ & $\begin{array}{c}\text { Total de cargos } \\
\text { comissionados } \\
\text { (exercidos até } \\
1890)\end{array}$ & $\begin{array}{c}\text { Total de } \\
\text { mandatos no } \\
\text { Poder } \\
\text { Legislativo } \\
\text { (exercidos até } \\
1890)\end{array}$ \\
\hline $\begin{array}{l}\text { Adriano } \\
\text { Nunes } \\
\text { Cardoso }\end{array}$ & $\begin{array}{l}\text { Antonina } \\
\text { (PR) }\end{array}$ & Empresário & $\begin{array}{l}\text { Partido } \\
\text { Liberal }\end{array}$ & 1 & 0 \\
\hline $\begin{array}{c}\text { Bento } \\
\text { Antônio de } \\
\text { Meneses }\end{array}$ & $\begin{array}{l}\text { Paranaguá } \\
\text { (PR) }\end{array}$ & Músico & - & 1 & 0 \\
\hline $\begin{array}{l}\text { Francisco } \\
\text { Joaquim } \\
\text { Bittencourt } \\
\text { da Silva }\end{array}$ & $\begin{array}{l}\text { Rio de } \\
\text { Janeiro } \\
(\mathrm{RJ})\end{array}$ & Arquiteto & - & 2 & 0 \\
\hline
\end{tabular}

Fontes: Dezenove de Dezembro (PR); Gazeta de Notícias (RJ); Gazeta Paranaense (PR); Jornal do Comércio (RJ); O Paranaense (PR); Província do Paraná (PR)

As informações expostas no Quadro 2 permitem salientar que os dirigentes do PO formaram uma chapa senatorial marcada pela presença de indivíduos que mantiveram ligações com membros de elites provinciais. Essas ligações favoreceram a absorção dos futuros candidatos a esquemas de nomeações para cargos comissionados. $\mathrm{O}$ fato de as chapas apresentadas pelo PO não conterem operários despertou a insatisfação de parte dos correligionários (GOULART, 2008, p.302). Assim, o surgimento dessa agremiação foi marcado por divergências quanto à definição de candidaturas.

De outra parte, cumpre demonstrar que uma semelhança entre uma parcela dos postulantes do PO reside no fato de que, ao tempo do Segundo Reinado, eles tiveram passagens ocasionais por agências da administração pública.

A esse respeito, atente-se ao caso de Adriano Nunes Cardoso. Ele era um empresário residente em Antonina, município do litoral paranaense. ${ }^{14}$ Cardoso não desenvolveu uma carreira política. Entretanto, pertenceu ao círculo social composto por personagens da elite dessa localidade. Um indício desse pertencimento consiste em sua participação, nos anos 1870, no Clube

${ }^{14}$ Uma das atividades empresariais de Adriano Cardoso consistiu em participar da criação, em 1893, da Companhia Tipográfica, a qual estava sediada em Curitiba (A REPÚBLICA, 11 mai. 1893, p.2). 
Democrático Antoninense. Dentre os indivíduos que contribuíram para a estruturação dessa entidade, estava o negociante ervateiro e ex-deputado provincial Antônio Alves de Araújo (DEZENOVE DE DEZEMBRO, 21 fev. 1874, p.4). Tal negociante era o líder do Partido Liberal em Antonina (OLIVEIRA, 2001).

Nesse âmbito, cumpre destacar uma aproximação entre o presidente do PO, Agostinho Leandro, e o candidato a senador Adriano Nunes Cardoso. A aproximação consiste no fato de que o ingresso em associações culturais, ao tempo do Império, foi decisivo para que eles consolidassem a sua socialização com membros das elites de municípios do litoral do Paraná. Assim, trata-se de salientar que Agostinho Leandro participou, em Morretes, de uma entidade cultural denominada Clube Alfa. Ao tempo de sua reorganização, em 1882, essa associação era presidida por José Antônio Lessa, que era Capitão da Guarda Nacional e possuía um tabelionato naquela cidade (GAZETA PARANAENSE, 20 set. 1882, p. 2$){ }^{15}$

A integração a círculos sociais compostos por personagens de elites locais não ocasionou, aos citados Agostinho Leandro e Adriano Cardoso, a acomodação em posições de relevo em partidos monárquicos. Porém, ambos os membros do PO se beneficiaram politicamente da integração àqueles círculos. Conforme acima ressaltado, a conquista do posto de presidente da Câmara de Morretes é um indício da solidez dos vínculos do presidente do PO com a elite política dessa cidade.

De outra parte, há evidências de que o comerciante Cardoso manteve um vínculo com o Partido Liberal. A demonstração dessa afirmação permite corroborar o argumento de que, em boa medida, os dirigentes e candidatos do PO possuíam um envolvimento na vida partidária e em órgãos da administração pública desde a época do Segundo Reinado. A ligação de Cardoso com os liberais paranaenses é identificada em um acontecimento do mês de junho de

\footnotetext{
${ }^{15}$ Em 1896, após um período desativado, o Clube Alfa retomou suas atividades. Nessa época, tal associação ainda contava com a participação de membros da elite morretense. No referido ano, por exemplo, o tesoureiro do clube era o negociante ervateiro e então deputado estadual Arsênio Gonçalves Cordeiro (A REPÚBLICA, 3 out. 1896, p.1).
} 
1889. Em tal contexto, o Partido Liberal retomou o comando do Gabinete Ministerial, o qual passou a ser presidido pelo Visconde de Ouro Preto. Por consequência, essa agremiação assumiu o controle dos esquemas de preenchimento de cargos públicos.

Adriano Cardoso foi beneficiado pela ascensão dos liberais à presidência do Gabinete. No referido mês, esse comerciante foi nomeado para o posto de $2^{\circ}$ suplente de Subdelegado do município de Antonina (DEZENOVE DE DEZEMBRO, 1 jul. 1889, p.1). A aproximação de Cardoso com os liberais paranaenses era anterior a tal acontecimento. ${ }^{16}$ Contudo, foi apenas tardiamente que ele conquistou a faculdade de obter um cargo cuja nomeação cabia aos chefes locais do partido.

Assim, um ano antes de se apresentar como candidato a senador pelo PO, Cardoso estava enquadrado na categoria de um correligionário do Partido Liberal. De fato, tal filiação não lhe assegurou a conquista de relevantes e estáveis posições na administração pública. A queda do Império ocasionou a sua exoneração do cargo que obtivera por intermédio dos líderes daquela agremiação (A REPÚBLICA, 8 abr. 1890, p.3).

Em última análise, Adriano Cardoso teve presença pouco duradoura na vida administrativa de Antonina. A sua condição de suplente de Subdelegado denota que ele estava em posição hierarquicamente inferior em relação a outros correligionários do Partido Liberal que se envolveram nas políticas de preenchimento de cargos públicos. Nos anos finais do Império, Cardoso não tinha o prestígio político suficiente para exercer, na condição de titular, os cargos comissionados existentes naquele município. A conquista de uma nomeação do Governo Provincial consistiu no limite dos benefícios advindos de sua ligação com os liberais de Antonina. Assim, a sua candidatura a senador

\footnotetext{
${ }^{16}$ Um indício das relações de Adriano Cardoso com os liberais do Paraná consiste no fato de que ele foi um dos signatários, em janeiro de 1888, de um abaixo-assinado alusivo a uma eleição ocorrida em dezembro de 1887. Nesse documento, liberais do litoral e do primeiro planalto paranaense endossaram os argumentos de uma parcela dos membros da Junta Apuradora do $2^{\circ}$ distrito eleitoral da província. Essa parcela de membros da Junta apresentou evidências de que os conservadores manipularam a contagem dos votos dos candidatos à Assembleia Legislativa (DEZENOVE DE DEZEMBRO, 21 jan. 1888, p.3).
} 
por um partido minoritário foi o momento de maior expressão de seu percurso político.

Cumpre, por consequência, desenvolver uma abordagem conexa acerca dos percursos de Bento Antônio de Meneses (1830-1902) e Francisco Bittencourt (1831-1911). A principal analogia que se identifica em ambas as trajetórias diz respeito à antiguidade dos vínculos que cultivaram com as elites políticas do Segundo Reinado. Tais indivíduos não mantiveram ligação formal com um partido. Em relação ao caso de Adriano Cardoso, eles permaneceram por mais tempo integrados a um núcleo social que contava com a presença de agentes da administração provincial e imperial.

Atente-se, inicialmente, ao percurso de Bento de Meneses. Datam do fim dos anos 1850 e do começo dos anos 1860 as escassas nomeações obtidas por tal indivíduo. Ao mesmo tempo, nota-se que foi limitado a tal contexto o envolvimento de Meneses em eventos políticos ocorridos na capital paranaense.

Compete afirmar que em 1859 ele obteve o posto de Alferes Porta Estandarte do $1^{\circ}$ Regimento de Cavalaria da Guarda Nacional em Curitiba (DEZENOVE DE DEZEMBRO, 16 jul. 1859, p.3). Em 1860, Meneses se tornou, por meio de nomeação do presidente da província, Mestre de Música da Companhia Policial de Curitiba (DEZENOVE DE DEZEMBRO, 19 mai. 1860, p.1).

De outra parte, data do ano de 1861 uma informação sobre a inserção de tal músico na vida política da capital paranaense. No mencionado ano, ele foi o sexagésimo indivíduo mais votado no processo de escolha dos eleitores de Curitiba. Meneses angariou, nessa ocasião, 36 sufrágios (DEZENOVE DE DEZEMBRO, 9 jan. 1861, p.4).

Há indícios de que ele cultivava relações com membros da cena política da província. Um desses indícios reside no fato de que, nos anos finais do Império, ele atuou como professor de Música de um estabelecimento particular, o Colégio Parthenon Paranaense. Localizada na cidade de Curitiba, essa 
instituição era dirigida pelo médico Laurentino de Azambuja, o qual pertenceu ao Partido Conservador (DEZENOVE DE DEZEMBRO, 21 fev. 1886, p.2). ${ }^{17}$

De outra parte, um episódio ocorrido em 1887 denota a existência de interações entre Meneses e os monarquistas da capital paranaense. Em tal ano, o referido músico fez parte de uma orquestra que se apresentou em um evento alusivo ao aniversário do imperador D. Pedro II. Esse evento teve um caráter oficial, visto que contou com a presença do presidente da província (DEZENOVE DE DEZEMBRO, 30 nov. 1887, p.4). Assim, ao tempo em que alguns dos futuros membros do PO já estavam vinculados ao movimento republicano, Meneses integrava um círculo social composto por entusiastas do regime político então vigente no país.

A carreira profissional de Meneses foi muito estável. Ele era localmente reconhecido como o responsável por estruturar a primeira banda pública da província. Nesse contexto, não se envolveu em querelas de ordem políticopartidária.

Cumpre, por fim, dedicar atenção ao caso do arquiteto Francisco Bittencourt. Para além de destacar aspectos convergentes quanto ao perfil social de membros do $\mathrm{PO}$, o estudo de tal caso permite salientar a extensão das conexões políticas dos dirigentes partidários do Paraná na mencionada época. Mais precisamente, cumpre ressaltar uma analogia quanto à natureza das ligações políticas cultivadas, fora do Paraná, pelos líderes do PO e do Partido Republicano.

Francisco Bittencourt era um funcionário do Governo Imperial. Ele lecionou na Academia Imperial de Belas Artes e na Escola Politécnica do Rio de Janeiro. O vínculo de tal indivíduo com o regime monárquico é evidenciado pelos títulos honoríficos que possuía. Em 1870, aos 39 anos de idade, ele já havia obtido duas condecorações: Cavaleiro da Ordem da Rosa e Cavaleiro da Ordem de Cristo (SILVA, 1870). Em meados dessa década, Bittencourt conquistou uma concessão do Governo Imperial. No ano de 1875, ele obteve

\footnotetext{
${ }^{17}$ Laurentino de Azambuja fez parte do núcleo dirigente do Partido Conservador paranaense em 1889, época em que Justiniano de Mello liderou a abertura de uma dissidência nessa agremiação (DEZENOVE DE DEZEMBRO, 16 mar. 1889, p.2).
} 
autorização do Governo para construir e explorar, na então capital brasileira, uma linha férrea voltada ao transporte de passageiros. ${ }^{18}$ Tal indivíduo, portanto, alcançou a condição de concessionário de serviço público.

Bittencourt possuía conexões sociais que ultrapassavam o âmbito de sua província de origem, o Rio de Janeiro. Ele aceitou se candidatar a senador pelo PO na época em que os republicanos históricos do Paraná também selecionaram alguns de seus candidatos no interior da sociedade carioca. A esse respeito, cumpre mencionar que um dos eleitos para a Câmara dos Deputados pelo Partido Republicano do Paraná em 1890 residia na cidade do Rio de Janeiro. Tratava-se do militar Marciano Augusto Botelho de Magalhães (1848-1930), irmão de Benjamin Constant Botelho de Magalhães (CASTRO, 1995). Assim, os próceres da citada agremiação concederam espaço em sua chapa a um indivíduo que possuía ligação familiar com um destacado participante do movimento republicano.

As lideranças operárias do estado, por sua vez, inseriram em sua chapa um indivíduo (Francisco Bittencourt) que se notabilizara pelas experiências na área do ensino profissional. Bittencourt foi o fundador, em 1856, do Liceu de Artes e Ofícios do Rio de Janeiro. No Segundo Reinado, esse estabelecimento ofereceu cursos técnicos a jovens, mulheres e operários. Havia, pois, um propósito social subjacente às atividades dessa instituição (BIELINSKI, 2003).

Outra semelhança entre o Partido Republicano do Paraná e o PO reside no fato de que foi pouco duradoura a presença de adventícios em seus quadros. A aliança dos dirigentes dessas agremiações com indivíduos oriundos da capital do Império não perdurou para além do pleito de $1890 .{ }^{19}$

\footnotetext{
${ }^{18}$ Essa autorização foi obtida Francisco Bitencourt em conjunto com Antônio Pinto Ferreira Morado. A linha de ferro se estenderia da Rua Primeiro de Março até o Morro do Pinto. Ambos os pontos estão situados na região central do Rio de Janeiro (COLEÇÃO DE LEIS DO IMPÉRIO, 1875, Vol. 2, Parte 2, p.386).

${ }_{19}$ A candidatura de Bittencourt a senador pelo Paraná foi o único momento de seu envolvimento na vida política do estado. De outra parte, cumpre salientar o caso do militar fluminense Belarmino Augusto Mendonça Lobo (1850-1913). Ele foi deputado federal pelo Paraná, de 1890 a 1893. Em 1899, tentou o segundo mandato de deputado federal por esse estado. Nessa ocasião, apresentou-se como candidato do Partido Republicano, uma agremiação oposicionista. Contudo, não conseguiu ser eleito. Ele obteve a quinta colocação no pleito. Nessa ocasião, havia quatro vagas em disputa e sete candidatos (ANAIS DA CÂMARA DOS DEPUTADOS, Vol. 1, 1900, p.102).
} 
Cumpre, por fim, dedicar atenção aos perfis sociais dos candidatos do PO à Câmara dos Deputados. O desenvolvimento dessa análise exige o estudo das informações apresentadas no Quadro 3.

Quadro 3 - Atuação política e profissional dos candidatos à Câmara dos Deputados pelo Partido Operário do Paraná

\begin{tabular}{|c|c|c|c|c|c|}
\hline Nome & $\begin{array}{c}\text { Município } \\
\text { de origem }\end{array}$ & Profissão & $\begin{array}{c}\text { Filiação } \\
\text { partidária } \\
\text { (anterior a } \\
\mathbf{1 8 9 0}\end{array}$ & $\begin{array}{c}\text { Total de cargos } \\
\text { comissionados } \\
\text { (exercidos até } \\
\mathbf{1 8 9 0}\end{array}$ & $\begin{array}{c}\text { Total de } \\
\text { mandatos no } \\
\text { Poder } \\
\text { Legislativo } \\
\text { (exercidos até } \\
\mathbf{1 8 9 0}\end{array}$ \\
\hline $\begin{array}{c}\text { Jorge } \\
\text { Joppert }\end{array}$ & $\begin{array}{c}\text { Deodoro } \\
\text { (PR) }\end{array}$ & Empresário & $\begin{array}{c}\text { Partido } \\
\text { Republicano }\end{array}$ & 0 & 0 \\
\hline $\begin{array}{c}\text { Manuel } \\
\text { Correia de } \\
\text { Freitas }\end{array}$ & $\begin{array}{c}\text { Paranaguá } \\
\text { (PR) }\end{array}$ & Jornalista & $\begin{array}{c}\text { Partido } \\
\text { Republicano }\end{array}$ & 0 & 0 \\
\hline $\begin{array}{c}\text { Norberto } \\
\text { de }\end{array}$ & $\begin{array}{c}\text { Curitiba } \\
\text { (PR) }\end{array}$ & Militar & - & 0 & 0 \\
$\begin{array}{c}\text { Amorim } \\
\text { Bezerra }\end{array}$ & Curitiba & Artista & & & 0 \\
\hline $\begin{array}{c}\text { Paulo } \\
\text { Ildefonso } \\
\text { de }\end{array}$ & plástico & & & & 0 \\
Assunção & & & & & 0 \\
\hline
\end{tabular}

Fontes: Dezenove de Dezembro (PR); Gazeta de Notícias (RJ); Gazeta Paranaense (PR); Jornal do Comércio (RJ); O Paranaense (PR); Província do Paraná (PR)

As informações inseridas no Quadro 3 possibilitam a fundamentação de duas constatações. Primeiro, nota-se que uma parte dos postulantes do PO à Câmara Federal adquirira experiência nas lides partidárias ao tempo do Segundo Reinado. Essa experiência foi conquistada por meio da participação no movimento republicano.

Manuel Correia de Freitas (1851-1932) foi um jornalista que ganhou projeção pelas conferências abolicionistas e republicanas que realizou. Nos anos finais do Império, ele cultivou ligações com lideranças políticas de distintas regiões do país (CORRÊA, 2006). Tal indivíduo se enquadra na categoria dos republicanos históricos que possuíam conexões com membros de elites locais e, em particular, com integrantes dos partidos monárquicos.

Nesse âmbito, cabe destacar que Correia de Freitas participou da fundação, em 1872, do Clube Literário de Paranaguá. Tal entidade era frequentada por componentes da elite econômica da cidade (SCHEIFER, 2008). 
Nos anos 1880, houve chefes locais do Partido Conservador que exerceram o comando dessa associação (O ITIBERÊ, 1884). Essas informações permitem corroborar o argumento de que, nas últimas décadas do século XIX, os sodalícios existentes em municípios do litoral do Paraná foram espaços de socialização entre futuros propagandistas da República e lideranças regionais dos partidos monárquicos.

Jorge Joppert, por seu turno, estava enraizado na vila de Deodoro (atual município de Piraquara). Essa localidade é adjacente à cidade de Curitiba. Joppert fez parte do grupo de republicanos que se beneficiou dos esquemas de nomeações que vigoraram no Paraná nos meses posteriores à queda do Império. A esse respeito, cumpre mencionar que, em janeiro de 1890, ele foi nomeado pelo governador do Paraná para integrar a Comissão Municipal da Vila de Deodoro. Essa Comissão tinha a tarefa de governar tal localidade (A REPÚBLICA, 4 fev. 1890, p.1). Porém, em meados daquele ano Joppert já não atuava na gestão da vila. Nessa época, ele se dedicava apenas a negócios particulares. $^{20}$

Havia, assim, um aspecto heterogêneo na composição social do rol de candidatos do PO. Uma parte dos integrantes desse rol já possuía algum renome político e profissional para além da Província do Paraná. Tais integrantes eram Manuel Correia de Freitas e Francisco Bittencourt.

Por outro lado, houve candidatos cuja atividade política era circunscrita a um município. Tais candidatos eram Adriano Cardoso e Jorge Joppert. De todo modo, há uma semelhança entre os casos de Correia de Freitas e Joppert. A semelhança reside no fato de que ambos se beneficiaram dos esquemas de nomeações para cargos públicos que vigoraram no estado após a queda do Império.

Em 1890, Freitas foi nomeado para o posto de Superintendente de Terras e Colonização do Paraná (A REPÚBLICA, 8 jan. 1890, p.1). Todavia, a sua permanência nesse cargo foi limitada aos primeiros três meses daquele ano.

\footnotetext{
${ }^{20} \mathrm{Em}$ tal contexto, Joppert mantinha um serviço de aluguel de carruagens na Vila de Deodoro (A REPÚBLICA, 16 jul. 1890, p.4).
} 
Após ser destituído da função, atuou como agente de seguros de vida (SETE DE MARÇO, 1890, 6 set. 1890, p.4). Em última análise, a perda de espaço nos esquemas de nomeações e a distância em relação aos chefes do Partido Republicano do Paraná o impeliram a ingressar em uma agremiação minoritária.

Em suma, o PO tinha entre os seus filiados indivíduos que, a despeito do histórico vínculo com os republicanos, não obtiveram decisivas oportunidades de atuação política após o fim do regime monárquico. A esses correligionários, o ingresso no PO permitiu a conquista de um espaço em chapas de candidatos.

A segunda constatação diz respeito ao fato de que as chapas do PO possuíam duas categorias de candidatos. Uma categoria era a dos republicanos históricos e antigos monarquistas que, no fim dos anos 1880, não exerciam expressiva influência na vida interna de suas agremiações de origem. A outra categoria era formada por novatos, isto é, indivíduos que não tinham vínculos prévios com agremiações partidárias. Acerca dos novatos, atente-se aos casos de Norberto Amorim e Paulo Ildefonso de Assunção.

Amorim era Major do Exército. Nesse quadro, convém destacar que a ação eleitoral do PO guardava uma semelhança com a ação dos partidos eleitoralmente mais fortes do estado. A semelhança reside no fato de que as agremiações mais competitivas também conferiram espaço a militares em suas chapas, ainda que estes não tivessem longa experiência na vida política. O PO, o Partido Republicano do Paraná e a União Republicana inseriram militares nas suas composições para a Câmara dos Deputados e o Congresso Estadual (DIÁRIO DO COMÉRCIO, 18 mar. 1891, p.3).

Paulo de Assunção, por sua vez, era estudante na Academia Imperial de Belas Artes ao tempo do fim do regime monárquico (DEZENOVE DE DEZEMBRO, 5 jan. 1889, p.2). Em 1890, quando se candidatou a deputado constituinte, ele era um jovem de 21 anos. Conforme salientado na seção seguinte desta investigação, a inexperiência política de Assunção foi evidenciada em sua irrisória votação. Nesse contexto, os candidatos mais competitivos do PO à Câmara dos Deputados eram aqueles que haviam 
participado do movimento republicano. Tais postulantes possuíam um longo envolvimento na organização de campanhas eleitorais (ALVES, 2014).

Da articulação à dispersão dos correligionários: o PO nas eleições estaduais e municipais dos anos 1890

Nesta seção é empreendida a análise da participação do PO em disputas eleitorais ocorridas nos anos de 1890 e 1896. Essa investigação possibilita reconhecer uma aproximação quanto às estratégias eleitorais adotadas por esse partido e pelas agremiações oposicionistas que funcionaram em distintos estados brasileiros na mencionada época. Para tanto, cumpre elaborar uma contextualização sobre a cena partidária que se formou no Paraná nos anos seguintes à queda do Império.

No período que abrange os anos de 1890 a 1893, o cenário político paranaense foi marcado pela coexistência de quatro agremiações. Trata-se de uma época de maior pluralidade na vida política do estado. Após tal época, não houve o funcionamento simultâneo de duas agremiações oposicionistas no estado. De meados dos anos 1890 até o ano de 1930, esse cenário foi marcado pelo enfrentamento entre o partido predominante e um partido de oposição, o qual não demorava a se dissolver após um malogro eleitoral (GOULART, 2008). Ao tempo da criação do PO, a agremiação predominante era o Partido Republicano, o qual era constituído por republicanos históricos e egressos do Partido Conservador. No campo da oposição, havia o PO, a União Republicana (UR) e o Partido Democrático (PD). Ao passo que a UR era controlada por antigos integrantes do Partido Liberal, o PD serviu como um refúgio para políticos que haviam pertencido ao Partido Conservador.

As derrotas eleitorais e a falta de um consistente enraizamento no interior do estado impediram que esses partidos permanecessem em atividade por longo tempo. Elas não participaram do jogo eleitoral para além dos anos 1890. Outra semelhança entre essas agremiações era quanto ao encerramento das carreiras de seus dirigentes. Conforme evidenciado neste trabalho, uma parte dos membros do PO se transferiu para partidos situacionistas. O fim das 
atividades do PD também foi marcado pela absorção de alguns de seus correligionários pelo grupo governista (NEGRÃO, 2004, p.318).

Havia um elemento que distinguia o PO dos demais partidos então existentes no Paraná. Tal elemento era a defesa de um preciso conjunto de ideias programáticas. Nessa época, agremiações como o PR e a UR permaneciam apegadas a uma prática inerente à vida política do Segundo Reinado. Tal prática consistia na produção das circulares eleitorais, as quais continham um pequeno conjunto de justificativas em defesa dos candidatos incluídos em uma chapa (DIÁRIO DO COMÉRCIO, 4 mar. 1891, p.3).

Os líderes do PO redigiram um manifesto de fundação do partido. Nele, apresentaram as suas sugestões para o enfrentamento de problemas sociais. Dentre as propostas do PO, estava a criação de institutos de previdência, orfanatos e escolas. Essa agremiação também defendia mudanças na legislação referente ao direto de herança. ${ }^{21}$

Em tal contexto, em diferentes estados, era candente o debate sobre ideias de matriz socialista. Essa discussão foi efetuada por agremiações operárias que surgiram em estados como Rio de Grande do Sul e São Paulo (CARONE, 1979; SCHMIDT, 2007). ${ }^{22}$ No Paraná, no período em tela, não foram apenas os líderes operários que realizaram discussões acerca das mazelas

\footnotetext{
${ }^{21}$ Os fundadores do PO eram também entusiastas das ideias sustentadas pelo Partido Operário do Rio de Janeiro. A criação de um Tribunal destinado a arbitrar as querelas entre operários e industriais era umas das propostas da agremiação operária criada na então capital da República. Essa proposta foi endossada por Justiniano de Mello e Silva (SETE DE MARÇO, 10 mai. 1890, p.1-2).

${ }^{22}$ No ano de 1890 , em distintos estados brasileiros, defensores das ideias socialistas tentaram se envolver no jogo eleitoral. A fundação de agremiações operárias no Paraná, Rio de Janeiro e Rio Grande do Sul é uma evidência dessa tentativa. Em boa medida, esses partidos foram constituídos por indivíduos que já estavam vinculados a associações operárias. O Clube dos Operários e Artífices do Paraná originou o PO. De outra parte, a integração entre membros de associações de classe do Rio de Janeiro originou um partido operário, cuja presidência foi exercida pelo músico Roberto Jope Kinsman Benjamin (1853-1934) (BATALHA, 2009). O Partido Operário fundado do Rio Grande do Sul também congregava integrantes de distintas ligas de trabalhadores. De todo modo, divergências internas $\mathrm{e}$ as dificuldades de contrabalançarem a força eleitoral das agremiações dominantes levaram os correligionários desses partidos a se desagregar (LONER, 2010). Assim, eram análogos os problemas enfrentados pelas agremiações operárias. Por conseguinte, foram pouco duradouras as iniciativas destinadas a manter partidos operários em atividade no contexto da Primeira República.
} 
sociais. Houve integrantes da elite econômica do estado que também se ativeram a esse tema. ${ }^{23}$

No caso do PO, a difusão das propostas sociais era realizada por meio de periódicos que pertenciam aos dirigentes do partido. Conforme ressaltado, o jornal Sete de Março, de Justiniano de Mello, era o órgão de divulgação das ideias do partido. Nos decênios de 1890 e 1900, o periódico Operário Livre, editado por Agostinho Leandro, também veiculou demandas de trabalhadores paranaenses (ARAÚJO e CARDOSO, 1992).

Nesse contexto, o PO possuía um grau de unidade mais elevado do que o existente entre os filiados ao Partido Operário da Bahia. Em 1890, as cizânias entre as lideranças dessa agremiação impediram que essa agremiação lançasse uma chapa às eleições para a Assembleia Nacional Constituinte (CASTELLUCCI, 2008). De todo modo, a união entre os membros do PO não foi acompanhada pela formação de ampla base eleitoral.

Uma das dificuldades enfrentadas por essa agremiação consistiu na aliança realizada entre os partidos eleitoralmente mais fortes. As agremiações predominantes do Paraná (PR e UR) lançaram chapa única na disputa pelas vagas à Assembleia Nacional Constituinte. Tratava-se, pois, da Chapa da Conciliação (DIÁRIO DO PARANÁ, 6 set 1890, p.1). Conforme evidenciado nas informações da Tabela 1, tais vagas foram integralmente preenchidas por candidatos ligados a ambos os partidos.

\footnotetext{
${ }^{23}$ No Paraná, no início do século XX, houve abastados negociantes de erva-mate que se dedicaram à reflexão sobre assuntos sociais. Dentre tais negociantes, estavam Antônio Ribeiro de Macedo (1842-1931) e David Antônio Carneiro Júnior (1879-1928) (CARNEIRO, 1965).
} 
Tabela 1 - Votação dos candidatos ao Senado Federal pelo Estado do Paraná (1890)

\begin{tabular}{c|c|c|c|c}
\hline Nome do candidato & $\begin{array}{c}\text { Filiação } \\
\text { partidária }\end{array}$ & $\begin{array}{c}\text { Votação (em } \\
\text { números } \\
\text { absolutos) }\end{array}$ & $\begin{array}{c}\text { \% da votação } \\
\text { do candidato }\end{array}$ & Resultado \\
\hline $\begin{array}{c}\text { Ubaldino do Amaral } \\
\text { Fontoura }\end{array}$ & $\begin{array}{c}\text { Partido } \\
\text { Republicano }\end{array}$ & 8.570 & 32,3 & Eleito \\
\hline $\begin{array}{c}\text { José Pereira dos } \\
\text { Santos Andrade }\end{array}$ & $\begin{array}{c}\text { Partido } \\
\text { Republicano }\end{array}$ & 7.781 & 29,4 & Eleito \\
\hline $\begin{array}{c}\text { Generoso Marques } \\
\text { dos Santos }\end{array}$ & $\begin{array}{c}\text { União } \\
\text { Republicana }\end{array}$ & 7.740 & 29,1 & Eleito \\
\hline $\begin{array}{c}\text { Francisco Cardoso } \\
\text { Júnior }\end{array}$ & $\begin{array}{c}\text { União } \\
\text { Republicana }\end{array}$ & 955 & 3,1 & Não eleito \\
\hline $\begin{array}{c}\text { Francisco Joaquim } \\
\text { Bittencourt da Silva }\end{array}$ & $\begin{array}{c}\text { Partido } \\
\text { Operário }\end{array}$ & 797 & 0,1 & Não eleito \\
\hline $\begin{array}{c}\text { Bento Antônio de } \\
\text { Meneses }\end{array}$ & $\begin{array}{c}\text { Partido } \\
\text { Operário }\end{array}$ & 25 & 0 & Não eleito \\
\hline $\begin{array}{c}\text { Adriano Nunes } \\
\text { Cardoso }\end{array}$ & $\begin{array}{c}\text { Partido } \\
\text { Operário }\end{array}$ & 1 & 2,4 & Não \\
\hline Outros (90) & - & 640 & & 3,6 \\
\hline
\end{tabular}

Fonte: A República (19 out. 1890, p.3).

As informações da Tabela 1 permitem a sustentação de três constatações. Primeiro, cabe destacar que os políticos veteranos que integraram a Chapa da Conciliação permaneciam eleitoralmente competitivos no início dos anos 1890. Nesse particular, cumpre mencionar que Generoso Marques dos Santos e José Pereira dos Santos Andrade foram adversários ao tempo do Império. Marques pertenceu ao Partido Liberal. Santos Andrade, por sua vez, integrou o Partido Conservador (OLIVEIRA, 2001). Dessa forma, os republicanos históricos que controlavam o Partido Republicano do Paraná permitiram que antigos monarquistas obtivessem o apoio necessário para continuarem em evidência na cena política do estado.

A segunda constatação afirma que uma pequena parcela do eleitorado não endossou as candidaturas dos partidos predominantes e minoritários que existiam nesse contexto no Paraná. Por consequência, houve uma profusão de nomes que receberam uma ínfima quantidade de votos. Nessa época, não havia um controle do Estado sobre o registro de candidaturas. Portanto, existiam ocasiões em que indivíduos que não se apresentavam como candidatos tinham os seus nomes registrados nas cédulas eleitorais. Esses sufrágios entravam no cômputo final dos votos (NICOLAU, 2012). Em síntese, nesse contexto de 
reorganização do quadro partidário uma parte dos eleitores não possuía identificação com as agremiações recém-constituídas.

A terceira constatação afirma que os candidatos do PO ao Senado tiveram desempenho eleitoral muito desigual. As regras de votação que regeram as eleições parlamentares de 1890 eram oriundas do Segundo Reinado. Conforme essas regras, o eleitor deveria votar em um número de candidatos equivalente ao total de vagas em disputa (NICOLAU, 2002).

Nesse quadro, a votação parelha dos postulantes governistas pode ser atribuída ao fato de que a maior parte dos eleitores da situação aceitou sem reservas os nomes contidos na Chapa da Conciliação. De outra parte, a expressiva vantagem de Francisco Bittencourt em relação aos demais membros da chapa do PO denota que a parcela majoritária dos eleitores desse arquiteto não encampou as outras duas candidaturas recomendadas pelo partido. Em síntese, os eleitores governistas apresentaram um nível maior de disciplina partidária em relação aos correligionários do PO.

Trata-se, pois, de estudar o desempenho do PO no pleito para as vagas de deputado à Assembleia Nacional Constituinte. Para tanto, cabe analisar as informações inseridas na Tabela 2.

Tabela 2 - Votação dos candidatos à Câmara dos Deputados pelo Estado do Paraná (1890)

\begin{tabular}{c|c|c|c|c}
\hline Nome do candidato & $\begin{array}{c}\text { Filiação } \\
\text { partidária }\end{array}$ & $\begin{array}{c}\text { Votação (em } \\
\text { números absolutos) }\end{array}$ & $\begin{array}{c}\text { \% da votação do } \\
\text { candidato }\end{array}$ & Resultado \\
\hline $\begin{array}{c}\text { Belarmino Augusto de } \\
\text { Mendonça Lobo }\end{array}$ & $\begin{array}{c}\text { Partido } \\
\text { Republicano }\end{array}$ & 8.711 & 24,7 & Eleito \\
\hline $\begin{array}{c}\text { Marciano Augusto } \\
\text { Botelho de Magalhães }\end{array}$ & $\begin{array}{c}\text { Partido } \\
\text { Republicano }\end{array}$ & 8.555 & 24,3 & Eleito \\
\hline $\begin{array}{c}\text { Eduardo Mendes } \\
\text { Gonçalves }\end{array}$ & $\begin{array}{c}\text { Partido } \\
\text { Republicano }\end{array}$ & 7.841 & 22,2 & Eleito \\
\hline $\begin{array}{c}\text { Fernando Machado de } \\
\text { Simas }\end{array}$ & $\begin{array}{c}\text { União } \\
\text { Republicana }\end{array}$ & 7.661 & 2,6 & Eleito \\
\hline $\begin{array}{c}\text { Norberto de Amorim } \\
\text { Bezerra }\end{array}$ & $\begin{array}{c}\text { Partido } \\
\text { Operário }\end{array}$ & 924 & 2,5 & Não eleito \\
\hline $\begin{array}{c}\text { Jorge Joppert } \\
\text { Opartido }\end{array}$ & 881 & 0,6 & Não eleito \\
\hline $\begin{array}{c}\text { Manuel Correia de } \\
\text { Freitas }\end{array}$ & $\begin{array}{c}\text { Partido } \\
\text { Operário }\end{array}$ & 220 & 0,1 & Não eleito \\
\hline $\begin{array}{c}\text { Paulo Ildefonso de } \\
\text { Assunção }\end{array}$ & $\begin{array}{c}\text { Partido } \\
\text { Operário }\end{array}$ & 35 & 1,3 & Não \\
Outros (87) & - & 475 & & 2 eitos \\
\hline
\end{tabular}

Fonte: A República (19 out. 1890, p.3). 
As informações presentes na Tabela 1 permitem a elaboração de três afirmações. Primeiro, trata-se de salientar que os candidatos eleitos para o posto de deputado constituinte eram membros fundadores do Partido Republicano. Assim, uma parcela dos participantes do movimento republicano paranaense conseguiu decisivas oportunidades de atuação na vida partidária a partir dos anos 1890 .

Segundo, compete ressaltar que na eleição para a Câmara também se verificou a existência de um pequeno contingente de eleitores que não endossou as candidaturas dos partidos estaduais então existentes no Paraná. Tal postura gerou a dispersão de votos em algumas dezenas de nomes. Em grande medida, esse acontecimento pode ser atribuído a um contexto de reformulação do quadro partidário.

Nesse período, uma parcela dos eleitores ainda se identificava com políticos do Segundo Reinado que não se apresentaram como candidatos no princípio da Primeira República. Dentre esses políticos, estava o ex-deputado provincial Trajano Joaquim dos Reis, que teve oito sufrágios no pleito para deputado constituinte. Nessa ocasião, o ex-deputado geral Manuel Alves de Araújo conquistou 36 votos na disputa para o Senado (A REPÚBLICA, 19 out. 1890, p.3).

Terceiro, convém salientar que o PO conseguiu angariar mais votos no pleito para deputado constituinte do que na eleição para senador. Tal constatação permite corroborar a afirmação de que uma parcela dos eleitores não atuou de forma disciplinada para apoiar as duas chapas lançadas pelo PO. Nessa época, já se notava que tal agremiação não possuía um amplo e estável conjunto de apoiadores. Por consequência, foram pouco numerosos os êxitos eleitorais desse partido.

$\mathrm{Na}$ última etapa deste estudo, cumpre demonstrar que a obtenção de mandatos legislativos por três membros do PO ocorreu em uma época na qual a agremiação predominante não apresentou chapas completas às eleições estaduais e municipais. Trata-se de destacar que a conquista desses mandatos 
foi derivada menos da consistente base eleitoral do partido do que de uma concessão eventual de seus antagonistas.

Em 1891, um ano após o surgimento do PO, uma parte dos fundadores e antigos candidatos desse partido foi cooptada pela União Republicana, que na época atuava como agremiação governista. Agostinho Leandro, Justiniano de Mello e Manuel Correia de Freitas e Norberto Amorim foram os membros do PO que se transferiram para o partido presidido por Generoso Marques, que na época exercia o cargo de governador (SÊGA, 2005). Filiados à UR, Amorim e Freitas conseguiram se eleger para o cargo de deputado estadual no mencionado ano (DIÁRIO DO COMÉRCIO, 8 mai. 1891, p.3).

De outra parte, o vínculo de Leandro com o referido partido lhe assegurou a indicação para o posto de membro da Intendência Municipal de Curitiba, órgão que tinha a incumbência de governar a cidade (DIÁRIO DO COMÉRCIO, 27 abr. 1891, p.3). A ligação de Justiniano de Mello com a UR também foi marcada pelo seu envolvimento em esquemas de nomeações. A esse respeito, cumpre salientar que, de 1891 a 1892, ele comandou a diretoria de Instrução Pública do Paraná (A REPÚBLICA, 30 jul. 1892, p.3).

Nos anos 1890, as vitórias eleitorais de Justiniano de Mello e Agostinho Leandro foram decorrentes da apresentação de chapas incompletas pelo partido predominante. No período em tela, houve dirigentes do Partido Republicano que sustentaram o entendimento segundo o qual às oposições deveria ser assegurado um terço das vagas em disputa para o Congresso do Legislativo do Paraná e a Câmara dos Deputados. Nas disputas para o cargo de deputado estadual, o terço significava dez vagas. Nas eleições para a Câmara, o terço representava uma vaga. De fato, houve partidos governistas de distintos estados que fizeram essa destinação aos seus adversários. Os situacionistas do Rio de Janeiro, por exemplo, realizaram tal concessão de forma eventual (FERREIRA, 1994).

Os governistas paranaenses tinham um entendimento volúvel sobre esse tema. Ou seja, ora se dispunham a ceder um terço das vagas aos seus adversários, ora se negavam a fazê-lo. No Paraná, a interrupção do lançamento 
de chapas incompletas aos cargos de deputado estadual e deputado federal ocorreu em 1915 (A REPÚBLICA, 12 out. 1915, p.1). A partir dessa época, os governistas exerceram o controle integral sobre os referidos cargos.

A disputa para o cargo de deputado estadual que ocorreu no Paraná, em 1892, resultou na eleição de Agostinho Leandro. Ele conquistou 636 sufrágios. Tal votação lhe conferiu a vigésima oitava posição entre os trinta eleitos para o Congresso Legislativo. Assim, ele fez parte do grupo de dez correligionários da UR que conseguiram um mandato em virtude da cessão de vagas aos situacionistas aos seus adversários (A REPÚBLICA, 17 fev. 1892, p.2). Nessa ocasião, já era marcante o desnível entre a força eleitoral dos governistas e oposicionistas do estado. Assim, somente com o artifício da vaga do terço os oposicionistas paranaenses conseguiam obter mandatos em instituições legislativas. $^{24}$

Por outro lado, compete salientar que em tal época surgiu nova entidade que se dispôs a representar os trabalhadores paranaenses em pleitos eleitorais. Tratava-se do Centro Operário Cosmopolita (COC). Essa agremiação apresentou, sem sucesso, candidatos às eleições estaduais de 1893 (A REPÚBLICA, 16 jun. 1893, p.3). Tal associação logo se extinguiu. Porém, o seu aparecimento denota que o PO não obteve ampla adesão do operariado do estado. O surgimento do COC e a absorção de líderes operários pela UR evidencia que o PO não teve êxito na tarefa de orientar a ação política dos trabalhadores por longo tempo.

A última participação conjunta dos membros fundadores do PO em uma eleição aconteceu em 1895. Em tal ano, os governistas continuavam a consentir que um terço das vagas do Congresso Legislativo do Paraná fosse preenchido pelos oposicionistas. Nessa oportunidade, Agostinho Leandro e Justiniano de Mello apresentaram-se candidatos a deputado estadual. Eles permaneciam vinculados à UR. Mais precisamente, esses antigos correligionários

\footnotetext{
${ }^{24}$ Para corroborar tal afirmação, cumpre mencionar que nesse pleito o situacionista menos votado, José Moraes, obteve 6.590 votos. Ele alcançou a vigésima colocação. O vigésimo primeiro colocado, o oposicionista Otoni Ferreira Maciel, angariou 1.095 sufrágios (A REPÚBLICA, 17 fev. 1892, p.2).
} 
conservavam a influência política necessária para serem inseridos nas chapas de candidatos do partido estadual de oposição.

No referido pleito, Mello amealhou 1.133 sufrágios. Tal votação lhe posicionou na vigésima sétima colocação. Agostinho Leandro obteve 1.102 votos e, por consequência, foi o quadragésimo colocado. Portanto, apenas Mello conseguiu se eleger nessa ocasião (A REPÚBLICA, 21 mar. 1895, p.2). Esse resultado evidencia que os fundadores do PO conservaram um pequeno rol de apoiadores. Tal grupo permitiu que a votação de alguns integrantes do partido fosse próxima àquela angariada por antigos parlamentares que tentavam voltar à cena política. Ou seja, o eleitorado dos antigos do PO era equivalente ao de uma parte dos políticos veteranos do estado. ${ }^{25}$

A oposição paranaense, em 1895, não possuía consistente apoio em cidades do interior. Eram raros os municípios em que os governistas não obtiveram os votos de parcela majoritária do eleitorado. Em tal ano, os oposicionistas suplantaram os situacionistas somente nas localidades de Conchas e Ipiranga, as quais estão situadas no segundo planalto do estado. ${ }^{26}$ Era muito acentuado, portanto, o controle que os governistas exerciam sobre a vida política da maior parte dos pequenos municípios.

Em tal época, os oposicionistas eleitos para o cargo de deputado estadual não desenvolviam uma consistente atividade parlamentar. Nesse contexto, deputados como Justiniano de Mello não possuíam a disposição para comparecer com assiduidade ao Congresso do Paraná. Esse bacharel assumiu o mandato apenas em janeiro de 1896 (A REPÚBLICA, 11 jan. 1896, p.1). Ou seja, ele participou somente do segundo e último ano da legislatura para a qual fora eleito. Assim, há indícios de que ao menos uma parte dos oposicionistas adotou uma postura absenteísta quanto aos seus compromissos parlamentares.

\footnotetext{
${ }^{25}$ No pleito estadual de 1895, o ex-deputado provincial Amazonas Marcondes, egresso do Partido Liberal, teve sucesso em sua candidatura. Ele obteve o mesmo número de votos de Justiniano de Mello. O jornalista José Francisco da Rocha Pombo, que fora deputado provincial pelo Partido Conservador no fim dos anos 1880, também se elegeu. Ele conquistou 1.123 sufrágios, uma votação ligeiramente menor que a de Mello (A REPÚBLICA, 19. mar. 1895, p.2).

${ }^{26} \mathrm{Na}$ vila de Conchas, a oposição obteve 97 votos. No povoado de Ipiranga, angariou 101 sufrágios. Em ambas as localidades, os governistas não receberam votos (A REPÚBLICA, 20 mar. 1895, p.2).
} 
Em resumo, não havia uma atuação unificada dos oposicionistas que exerciam mandato no Legislativo Estadual. ${ }^{27} \mathrm{O}$ mandato de deputado estadual foi o único cargo eletivo exercido por Mello durante a Primeira República. Em 1897, ele regressou a Sergipe (ALVES, 2014). Conforme acima ressaltado, os líderes do Partido Operário da Bahia também se distanciaram no início dos anos 1890. Porém, eles se reaproximaram em 1893 (CASTELLUCCI, 2008). No Paraná, a aliança entre os fundadores da primeira agremiação operária não foi reconstituída.

Em síntese, o rompimento dos vínculos entre os primeiros gestores do PO foi iniciado nos anos seguintes às eleições de 1890. Foi efêmera a aliança política entre tais gestores. Para atestar tal afirmação, cumpre destacar que o citado João Crispim foi incluído na chapa de candidatos a vereador de Curitiba apresentada pelo Partido Democrático em 1892 (GOULART, 2008, p.310). Ou seja, ele se vinculou a uma agremiação composta por egressos do Partido Conservador. Crispim não foi eleito. Ao mesmo tempo, não há registro de sua participação em outras disputas eleitorais. Dessa forma, esse artífice se enquadra na categoria das lideranças operárias cuja atividade política foi apenas circunstancial.

Data do ano de 1896 uma informação que também evidencia uma mudança no grupo de gestores do PO. Nessa época, tal agremiação era comandada por quatro indivíduos que não pertenciam ao rol de fundadores do partido. No citado ano, os membros da Comissão Executiva do PO eram Décio Antônio da Costa Mesquita, João Fernandes da Cunha, José Francisco Garrido e Teodorico Lassala Freire (A REPÚBLICA, 21 ago. 1896, p.3). Nesse contexto, portanto, uma nova geração de lideranças operárias havia se incumbido da tarefa de reativar a agremiação e envolvê-la nas disputas eleitorais.

\footnotetext{
${ }^{27}$ O jornal governista A República saudou a posse de Justiniano de Mello como um prenúncio da retomada da atividade legislativa dos oposicionistas paranaenses: "Oxalá o procedimento do ilustre Dr. Justiniano de Mello estimule os seus companheiros de representação ao cumprimento de seus deveres de representantes do Estado" (A REPÚBLICA, 11 jan. 1896, p.1).
} 
Naquele ano, o PO lançou dois candidatos no pleito para as doze vagas de vereador de Curitiba. Portanto, no regresso dessa agremiação ao jogo eleitoral os objetivos eram mais modestos. O PO abandonara o propósito de apresentar chapa completa. Assim, ele passou a se comportar como uma típica agremiação minoritária que contém suas ambições eleitorais ao reconhecer o domínio do partido governista sobre o jogo eleitoral. De todo modo, os candidatos do PO conseguiram se eleger nessa ocasião pelo fato de que os governistas lançaram chapa incompleta, a qual continha sete postulantes.

Ao mesmo tempo, cumpre destacar que os candidatos operários foram os menos votados dentre os eleitos. Esses postulantes eram Teodorico Lassala Freire e Manuel Ferreira Bello. Ao passo que Freire angariou 415 votos, Bello auferiu 402 sufrágios (A REPÚBLICA, 23 set. 1896, p.2). Assim, o êxito eleitoral de seus membros era dependente a abertura das vagas aos representantes de grupos políticos minoritários.

Em 1896, o partido também lançou um candidato ao Congresso Legislativo do Paraná. Um fator que estimulou esse lançamento consistiu na apresentação de chapa incompleta pelos situacionistas. $\mathrm{O}$ candidato apresentado pelo PO era o alfaiate Antônio Pospissil Júnior (A REPÚBLICA, 21 ago. 1896, p.3). A existência das vagas da minoria the permitiu conquistar uma cadeira ao Congresso estadual. Porém, ele foi o menos votado dentre os eleitos. Pospissil Júnior angariou 719 votos (A REPÚBLICA, 23 set. 1896, p.2). Desse modo, em eleições estaduais e municipais os postulantes do PO conseguiram se eleger em virtude do artifício da apresentação de chapas incompletas pelo partido dominante.

Nessa ocasião, o fato de o PO ter homologado apenas uma candidatura a deputado estadual evidencia que esse partido empregava uma prática comum às agremiações minoritárias da Primeira República. Tal prática consistia em lançar candidatura única para evitar a dispersão de votos do partido em postulantes pouco competitivos. Ao concentrar os votos em um candidato eleitoralmente mais forte, as pequenas agremiações buscavam assegurar um espaço mínimo nas instituições legislativas (FIGUEIREDO, 2016). 
Todavia, Pospissil Júnior não permaneceu por longo tempo filiado ao PO. Em 1897, ele se desligou desse partido. Em tal ano, esse alfaiate se recusou a disputar a reeleição de deputado estadual pelo PO (A REPÚBLICA, 29 mai. 1897, p.2). Portanto, verifica-se que no fim dos anos 1890 essa agremiação ainda possuía dificuldades para manter seus filiados unidos por longo tempo.

Na eleição estadual de 1897, Agostinho Leandro também tentou uma vaga no Congresso Legislativo. Contudo, experimentou nova derrota. Nessa época, ele permanecia vinculado ao grupo político de Generoso Marques. Esse grupo estava reunido em uma agremiação denominada Partido Republicano. ${ }^{28}$

Nessa ocasião, Agostinho Leandro angariou 1.182 votos. Essa votação lhe conferiu a trigésima sétima colocação no pleito. Eram trinta vagas em disputa (A REPÚBLICA, 14 jul. 1897, p.3). Nota-se, pois, que ele teve nesse pleito uma quantidade de votos ligeiramente superior àquela que obtivera em 1895. Portanto, nos anos finais de sua carreira política Agostinho Leandro se acomodou na condição de candidato pouco competitivo de uma agremiação oposicionista. Ele perdeu a sua condição de dirigente partidário. Os malogros eleitorais que experimentou no fim dos anos 1890 levaram ao encerramento de suas atividades partidárias. ${ }^{29}$

Na época da eleição estadual de 1897, Pospissil Júnior tornou-se membro do PRF, a agremiação predominante (A REPÚBLICA, 24 jul. 1897, p.1). Posteriormente, Teodorico Lassala Freire se vinculou ao grupo governista (A REPÚBLICA, 29 jan. 1907, p.2). Desse modo, a mudança de partido foi um aspecto do destino político de uma parte dos expoentes do PO. Assim, os membros de diferentes diretorias desse partido se assemelhavam pelo fato de que foi breve o seu envolvimento no projeto de consolidar uma agremiação estadual de oposição. A conquista de cargos comissionados foi outro elemento inerente ao percurso político dos membros do PO que migraram para o campo

\footnotetext{
${ }^{28}$ Nesse contexto, a agremiação governista adotava a denominação de Partido Republicano Federal (PRF).

${ }^{29}$ Em 1904, ano de seu falecimento, Agostinho Leandro permanecia como proprietário de jornal operário e de um hotel (A REPÚBLICA, 8 jun. 1904, p.1). Nessa época, ele também atuou como advogado provisionado (A REPÚBLICA, 12 dez. 1903, p.2). No começo dos anos 1890, Leandro ainda se envolvia em ações beneficentes (A REPÚBLICA, 22 jun. 1903, p.2). Entretanto, nesse contexto ele já estava afastado dos partidos e do jogo eleitoral.
} 
da situação. ${ }^{30} \mathrm{O}$ exercício desses cargos não foi incomum entre indivíduos que participaram de criação de outras agremiações operárias. ${ }^{31}$

Após a eleição estadual de 1896, o PO não se reorganizou para apresentar novas candidaturas. Entre os decênios de 1900 e 1920, os operários paranaenses participaram de eleições somente de modo ocasional. Em 1908, por exemplo, trabalhadores da cidade de Curitiba lançaram, sem êxito, uma chapa de candidatos aos cargos de vereador e juiz distrital (DIÁRIO DA TARDE, 18 jun. 1908, p.2). O lançamento dessa chapa, contudo, não foi acompanhado por novos esforços para a criação de um partido operário.

Criada em 1906, a Federação Operária Paranaense (FOP) teve uma participação mais longeva do que o PO na cena política do estado. Em 1930, a FOP permanecia em atividade. No plano eleitoral, essa associação se comportava como um partido minoritário que não ambicionava o controle integral nas vagas em disputa para cargos legislativos. ${ }^{32}$

Dentre os membros fundadores do PO, Manuel Correia de Freitas foi o único que permaneceu politicamente ativo no decorrer das décadas de $1900 \mathrm{e}$ 1910. Nesse contexto, exerceu um mandato de deputado estadual e foi deputado federal em duas legislaturas. Os seus êxitos eleitorais decorriam ora da abertura da vaga do terço, ora da vinculação ao partido governista. O destino político de Correia de Freitas após se desligar do PO foi caracterizado pela manutenção de

\footnotetext{
${ }^{30} \mathrm{O}$ ingresso de Pospissil Júnior no partido predominante não foi acompanhado pela conquista de novos mandatos eletivos. O principal efeito de sua aproximação com os situacionistas do Paraná foi o envolvimento em esquemas de preenchimento de cargos públicos. Um dos cargos por ele obtido foi o de Aferidor (fiscal) da Prefeitura de Curitiba. Em 1905, um ano antes de seu falecimento, tal indivíduo ainda exercia essa função (A REPÚBLICA, 13 out. 1905, p.2). Em suma, Pospissil Júnior não conquistou posições decisivas na administração pública a partir de sua adesão ao partido oficial.

${ }^{31}$ Nesse âmbito, atente-se ao caso do citado Roberto Kinsman Benjamin. No contexto dos anos 1910, ele foi nomeado para desempenhar uma função diplomática, a saber, Cônsul Geral de Honduras e Nicarágua (JORNAL DO BRASIL, 17 set. 1918, p.6). Em resumo, não era infrequente que dirigentes de entidades operárias cultivassem vínculos sociais que lhes facultavam o acesso a cargos de destaque. Por outro lado, convém reconhecer a extinção de um partido operário não implicava, em todos os casos, o afastamento de seus dirigentes de iniciativas de interesses dos trabalhadores. Roberto Kinsman, por exemplo, organizou a Sociedade Cooperativa Nacional em 1896 (JORNAL DO BRASIL, 10 jan. 1896, p.1).

${ }^{32}$ Em 1930, por exemplo, a FOP lançou a candidatura do empresário Gastão Chaves a uma das quatro vagas de deputado federal pelo Paraná. Contudo, esse candidato obteve apenas oitava colocação dentre os doze votados. Gastão Chaves angariou 3.490 votos, os quais equivaliam a 2,1\% do total de sufrágios (O DIA, 10 abr. 1930, p.1).
} 
instável relação com os partidos de oposição e de situação que funcionaram no Paraná (VANALI, 2017).

\section{Considerações finais}

Por meio de um estudo de caso, a presente abordagem buscou avançar no entendimento acerca da organização interna e da desagregação dos partidos operários que surgiram no interior do Brasil, mais especificamente no Estado do Paraná, no princípio da Primeira República. Há três resultados centrais apresentados neste trabalho.

Primeiro, foi evidenciado que uma parte dos fundadores do PO era constituída por indivíduos que adquiriram um treinamento nas lides partidárias no contexto do Segundo Reinado. O início da vida política de uma parcela desses fundadores foi marcado pela presença em círculos sociais compostos por membros de elites locais. Em casos como os de Agostinho Leandro e Justiniano de Mello, o ingresso em tais círculos foi acompanhado pela filiação a um partido monárquico. $\mathrm{O}$ vínculo a essas elites assegurou a futuras lideranças operárias a obtenção de cargos públicos e o exercício ocasional de mandatos.

Segundo, cumpre mencionar que uma parte dos componentes do PO participou do movimento republicano que se desenvolveu no Paraná nos anos 1880. Um desses componentes, Manuel Correia de Freitas, ganhou notoriedade em virtude dessa participação. Porém, os republicanos históricos que aderiram ao PO não obtiveram relevantes oportunidades políticas no período imediatamente posterior à queda do Império. Assim, o ingresso nessa agremiação minoritária foi uma forma de eles permanecerem envolvidos na cena partidária do estado.

Terceiro, cabe mencionar que foram escassos os êxitos eleitorais de candidatos ligados ao PO. Os motivos desses êxitos eram análogos àqueles que permitiram a eleição de membros dos pequenos partidos de distintos estados brasileiros. Na Primeira República, a obtenção de um mandato pelos postulantes oposicionistas era propiciada pelo lançamento de uma chapa incompleta de candidatos situacionistas. 


\section{Referências}

ALVES, Alessandro Cavassin. A Província do Paraná (1853-1889. Tese (Doutorado em Sociologia) - Universidade Federal do Paraná. Curitiba, 2014.

ARAÚJO, Sílvia; CARDOSO, Alcina. Jornalismo e militância operária. Curitiba: Ed. UFPR, 1992.

BATALHA, Claudio. Dicionário do movimento operário. São Paulo: Fapesp/Annablume, 2009.

BEGA, Maria Tarcisa Silva. Letras e política no Paraná. Curitiba: Ed. UFPR, 2013.

BIELINSKI, Alba Carneiro. Liceu de Artes e Ofícios do Rio de Janeiro. Dissertação (Mestrado em Artes Visuais) - Universidade Federal do Rio de Janeiro. Rio de Janeiro, 2003.

BILHÃO, Isabel. Rivalidades e solidariedades no Movimento Operário (Porto Alegre, 1906-1911). Porto Alegre: Ed. PUCRS, 1999.

CARNEIRO, Newton. Um precursor da justiça social. Curitiba: s/e, 1965.

CARONE, Edgard. O Movimento Operário no Brasil (1877-1944). São Paulo: Difel, 1979.

CARVALHO, José Murilo de. A construção da ordem /Teatro das sombras: a política imperial. $3^{\mathrm{a}}$ ed. Rio de Janeiro: Civilização Brasileira, 2007.

CASTELLUCCI, Aldrin. Trabalhadores, máquina política e eleições na Primeira República. Tese (Doutorado em História) - Universidade Federal da Bahia. Salvador, 2008.

CASTRO, Celso. Os militares e a República. Rio de Janeiro: Jorge Zahar, 1995.

CHACON, Vamireh. História dos partidos brasileiros. Brasília: Ed. UnB, 1981.

CHARLE, Christophe. A prosopografia ou biografias coletivas. In: HEINZ, Flávio (Org.). Por outra história das elites. Rio de Janeiro: Ed. FGV, 2006, p. 41-54.

CHAVES, Maria; VARGAS, Túlio. Sérgio de Castro. Curitiba: LíteroTécnica, 1987. 
CORRÊA, Amélia Siegel. Imprensa e política no Paraná. Dissertação (Mestrado em Sociologia) - Universidade Federal do Paraná. Curitiba, 2006.

DOMINGUES, Petrônio. Minervino de Oliveira. Lua Nova, São Paulo, v. 101, p. 13-51, 2017.

FABRIS, Pamela Beltramin. Agostinho Leandro da Costa. In: Anais do $\mathbf{9}^{\mathbf{o}}$ Encontro Escravidão e Liberdade no Brasil Meridional. Florianópolis: s/e, 2019, p. 1-14.

FABRIS, Pamela Beltramin; MENDONÇA, Joseli Maria Nunes. Os trabalhadores têm cor. In: GRUNER, Clóvis; RIBEIRO, Luiz Carlos (Org.). Utopias e experiências operárias. São Paulo: Intermeios, 2019, p. 75-92.

FAUSTO, Boris. Trabalho urbano e conflito social. São Paulo: Difel, 1976.

FERRARI, Marcela. Prosopografía e historia política. Antíteses, Londrina, v. 3, n. 5, p. 529-550, 2010.

FERREIRA, Marieta de Moraes. Em busca da Idade de Ouro. Rio de Janeiro: Editora da Universidade Federal do Rio de Janeiro/Edições Tempo Brasileiro, 1994.

FIGUEIREDO, Vítor Fonseca. Voto e competição política na Primeira República. Tese (Doutorado em História) - Universidade Federal de Juiz de Fora. Juiz de Fora, 2016.

FONSECA, Ricardo Marcelo; GALEB, Marcelo. A Greve Geral de 1917 em Curitiba. Curitiba: Factum, 2017.

GOULART, Mônica Helena Harrich Silva. Classe dominante e jogo político na Assembleia Legislativa Paranaense (1889-1930). Tese (Doutorado em Sociologia) - Universidade Federal do Paraná. Curitiba, 2008.

KAREPOVS, Dainis. A classe operária vai ao Parlamento. São Paulo: Alameda, 2006.

LINHARES, Hermínio. Contribuição à história das lutas operárias no Brasil. São Paulo: Alfa-Ômega, 1977.

LOBO, Eulália Maria Lahmeyer. Rio de Janeiro operário. Rio de Janeiro: Acces, 1992.

LONER, Beatriz. Construção de classe. Pelotas: Ed. UFPEL, 2001.

LONER, Beatriz. O projeto das ligas operárias do Rio Grande do Sul no início da República. Anos 90, Porto Alegre, v. 17, n. 31, p. 111-143, 2010. 
MACEDO, Joaquim Manuel de. Anno Biographico Brazileiro. Vol. 1. Rio de Janeiro: Tipografia do Imperial Instituto Artístico, 1876.

NEGRÃO, Francisco. Genealogia Paranaense. Vol. 2. Curitiba: Imprensa Oficial do Paraná, 2004.

NICOLAU, Jairo. As eleições no Brasil. Jorge Zahar, 2012.

NICOLAU, Jairo. História do voto no Brasil. Rio de Janeiro: Jorge Zahar, 2002.

OLIVEIRA, Ricardo Costa de. O silêncio dos vencedores. Curitiba: Moinho do Verbo, 2001.

PEREIRA, Leonardo Affonso de Miranda. A dança da política. Revista Brasileira de História, São Paulo, v. 37, n. 74, p. 63-88, 2017.

PETERSEN, Silvia Regina Ferraz. Que a União Operária seja a nossa pátria. Santa Maria: Ed. UFSM, 2001.

PRADO, Carlos Batista. Partidos e Sindicatos. Tese (Doutorado em História) - Universidade Federal Fluminense. Niterói, 2019.

SACCOL, Tassiana Maria Parcianello. De líderes históricos a opositores. Tese (Doutorado em História) - Universidade Católica do Rio Grande do Sul. Porto Alegre, 2018.

SAMPAIO, Consuelo Novais. Partidos políticos da Bahia na Primeira República. $2^{a}$ ed. Salvador: Ed. UFBA, 1999.

SANTOS, Antônio Vieira dos. Memória Histórica, Cronológica e Descritiva da Vila de Morretes. Curitiba: Museu Paranaense, 1950.

SAYÃO, Thiago Juliano. As heranças do Rosário. Revista Brasileira de História, São Paulo, v. 35, n. 69, p. 131-154, 2015.

SCHEIFER, Bruna. Paranaguá, cidade portuária. Dissertação (Mestrado em História) - Universidade Estadual do Oeste do Paraná. Marechal Cândido Rondon, 2008.

SCHMIDT, Benito Bisso. Em busca da terra da promissão. Porto Alegre: Palmarinca, 2004.

SCHMIDT, Benito Bisso. Os partidos socialistas na nascente República. In: FERREIRA, Jorge; REIS, Daniel Aarão. A formação das tradições (18891945). Vol. 1. Rio de Janeiro: Civilização Brasileira, 2007, p. 131-183. 
SCHMIDT, Benito Bisso. Um socialista no Rio Grande do Sul. Porto Alegre: Ed. UFRGS, 2000.

SÊGA, Rafael Augustus. Tempos belicosos. Curitiba: Aos Quatro Ventos, 2005.

SILVA, Inocêncio Francisco da. Diccionario Bibliographico Portuguez. Tomo 9. Lisboa: Imprensa Nacional, 1870.

SIMAS, Hugo. Paranaguá e a República. Curitiba: Edição Dicesar Plaisant, 1940.

STONE, Lawrence. Prosopografia. Revista de Sociologia e Política, Curitiba, v. 19, n. 39, p. 115-137, 2011.

TORRES, João Camilo de Oliveira. Democracia coroada. Brasília: Edição da Câmara dos Deputados, 2017.

VANALI, Ana Christina. "Ao povo paranaense". Tese (Doutorado em Sociologia) - Universidade Federal do Paraná. Curitiba, 2017.

VASCO, Edimeri Stadler. A cultura do trabalho em Curitiba de 1890 a 1920. Dissertação (Mestrado em História) - Universidade Federal do Paraná. Curitiba, 2006.

VERNALHA, Milton Miró. Da Monarquia à República. Curitiba: LíteroTécnica, 1989.

Recebido em: 07 de junho de 2020

Aceito em: 10 de julho de 2021 